\title{
Analgesic and anti-inflammatory activity of crude leaf and bark extract of Lantana Camara
}

\author{
Shripad M BAIRAGI, Inayat Bashir PATHAN, Nitin NEMA
}

\begin{abstract}
The purpose of present study was to investigate the analgesic and anti-inflammatory activity of Lantana camara (Verbenaceae) leaf and bark extract. The methanol extract of Lantana camara (MELC) was screened for possible analgesic activity by acetic acid, hot plate and anti-inflammatory activity by carrageenan and histamine induced paw edema. The result showed that, MELC $(100 \mathrm{mg} / \mathrm{kg}$ and $200 \mathrm{mg} / \mathrm{kg}$ ) leaf and bark possessed significant $(P<0.01$ and $P<0.05)$ anti-inflammatory response and $200 \mathrm{mg} / \mathrm{kg}$ dose of MELC leaf and bark showed more
\end{abstract}

significant $(P<0.01)$ analgesic activity as compared to the 100 $\mathrm{mg} / \mathrm{kg}$ dose. Preliminary phytochemical screening result shows the presence of several phytochemicals which may responsible for its anti-inflammatory and analgesic actions. The results indicate the MELC showed great potential for analgesic and anti-inflammatory activity and may be useful for the medical purpose.

Keywords: Lantana camara; anti-inflammatory activity; analgesic activity.
Shripad M Bairagi

University of Pune, Department of Pharmacology, Maharashtra, India

Inayat Bashir Pathan

Government College of Pharmacy, Department of Pharmaceutics, Maharashtra, India.

\section{Nitin Nema}

Department of Pharmacology, Sagar Institute of Pharmaceutical Sciences, Sagar M.P. India

\section{Corresponding Author:}

Shripad M Bairagi

e-mail:

ssanandss@yahoo.com

Submitted / Gönderilme: 27.12.2016 Revised / Düzeltme: 09.04.2017

Accepted / Kabul: 25.04.2017

How to cite this article: Bairagi SM, Pathan IB, Nema N. Analgesic and Anti-Inflammatory Activity of Crude Leaf and Bark Extract of Lantana Camara. Marmara Pharm J 2017; 21 (4): 810-817

\section{Introduction:}

From the thousands of the years, many countries are using the plants as a source of traditional medicine. Various Indian systems (Ayurveda, Unani, and Siddha) were using medicinal plants and their extracts for the treatment of various disorders [1]. The chemical diversity of plants has made them one of the main sources for the isolation of the active compounds. Inflammation is generally treated by opioids and nonsteroidal anti-inflammatory drugs (NSAIDs). Severe side effects are produced by the both the class like renal damage, GI disturbances, and respiratory depression. Traditionally used plant show different uses $[2,3]$.

Though the different type of analgesic and anti-inflammatory agents are available in the market, to overcome their side effects, searching for the new effective agent from plant source is still progressing [4].

Lantana camara comprises about 150 varieties over 50 countries. It is evergreen shrub commonly called as wild sage and lantana weed. Different species of lantana have been used from many years in the treatment and medical condition such as for the ulcers, cuts, tumor, eczema [5-8]. 
Various plant parts reported for its pharmacological properties like anti-lymphocytic and immunosuppressive, hepatoprotective, antimotility, anti-filarial, in-vivo cytotoxic and antimicrobial activity [9-12].

On the basis of above findings, the present work was performed to investigate the analgesic and anti-inflammatory potential of L. camara leaves methanol extract in different animal models.

\section{Materials and methods}

\section{Collection and identification of plant material:}

The leaf and bark of Lantana camara were procured from MPKV, Rahuri, Maharashtra, India. The identity of plant specimen is confirmed by botanist Dr. J. Jayanthi (HOD, Scientist, Govt. of India, BSI, Western, Regional Centre, Pune). A voucher with number SOSLAC2 was deposited to BSI, Pune.

\section{Extraction of plant material:}

The leaves and bark of plant was collected and washed thoroughly in distilled water and bark cut into small pieces. The leaves and bark was shade dried at room temperature. Dried parts were consistently ground using the mechanical grinder to make delicate powder. The soxhlet apparatus used for the extraction process, $100 \mathrm{~g}$ powdered of leaves and bark was separately extracted in methanol. The filtrate was concentrated by using rotary evaporator for methanol elimination and both the extract were preserved for further use [13].

\section{Drugs and chemicals}

The reference standard drugs pentazocine and indomethacin was commercially purchased. The Carrageenan and acetic acid were obtained from Himedia Lab, Mumbai, India.

\section{Preliminary Phytochemical screening}

The phytochemical analysis of the extracts was carried out as per the standard procedure [14-16].

\section{Experimental animals:}

The animals were procured from NTC, Pune, India and kept under the standard conditions like temperature, humidity and light/dark cycle, and provide them standard diet and allowed to drink water ad libitum. For evaluation of analgesic and anti-inflammatory activity wistar albino rat (180-200g) and Swiss albino mice (25-30g) were used. The experiments were carried out as per the standards of institutional animal ethical committee guidelines for the care of laboratory animals of MES College of Pharmacy, Sonai, India. The protocol was approved by IAEC no. MESCOP-1211/PO/Re/ S08/CPCSEA.

\section{Acute toxicity}

As per the Organization for Economic Cooperation and Development guidelines the acute oral toxicity study on wistar albino rat was performed [17].

\section{Anti-inflammatory activity}

Carragennan induced paw edema

The overnight fasted rats administered both the extracts, after $1 \mathrm{~h}$ the carragennan $(1 \% \mathrm{w} / \mathrm{v})$ suspension administered in the right hind paw by sub-planter injection to induce the inflammation. The six groups were prepared, each group consists six animals. The first group received $0.9 \%$ normal saline in $3 \%$ Tween $80(2 \mathrm{ml} / \mathrm{kg})$, and served as negative control, the second group received indomethacin $(10 \mathrm{mg} /$ $\mathrm{kg}$ ), and served as a positive control, the third and fourth group received $100 \mathrm{mg} / \mathrm{kg}$ and $200 \mathrm{mg} / \mathrm{kg}$ leaves extract, the fifth and sixth group received $100 \mathrm{mg} / \mathrm{kg}$ and $200 \mathrm{mg} /$ $\mathrm{kg}$ bark extract. After carragennan injection the animals were observed for change in paw volume at $0,1,3,4$ and 5 $\mathrm{h}$, the volume is measured by plethysmographically. Drugs were freshly prepared just before oral administration [18, 19].

Histamine induced paw edema

The $0.1 \%$ freshly prepared solution of histamine was used to induce the paw edema to the right hind paw of rats by sub-plantar administration. The change in paw volume was recorded at 0 and $1 \mathrm{~h}$ after histamine injection. Animals were divided into various groups to receive the leaves and bark extract (100 and $200 \mathrm{mg} / \mathrm{kg}$ ) with $0.9 \%$ normal saline in $3 \%$ Tween $80(2 \mathrm{ml} / \mathrm{kg})$ as a negative control and indomethacin were administered at $10 \mathrm{mg} / \mathrm{kg}$ dose and serve as positive control. Prior to eliciting the paw edema the drugs and extracts were administered [20,21]. 


\section{Analgesic activity:}

Acetic acid induced writhing:

The six groups of swiss albino mice were prepared with six animals in each group. The first group received normal saline $3 \%$ Tween $80(2 \mathrm{ml} / \mathrm{kg})$, and serve as a normal control, the acetylsalicylic acid (100 $\mathrm{mg} / \mathrm{kg}$ ) received by second group, group third and fourth received 100 and $200 \mathrm{mg} / \mathrm{kg}$ leaves extract, where as fifth and sixth group received 100 and $200 \mathrm{mg} / \mathrm{kg}$ bark extract. One hour after administration of extract the acetic acid $0.6 \% \mathrm{v} / \mathrm{v}(10 \mathrm{ml} / \mathrm{kg}$, i.p.) was injected to the positive and negative control groups. After acetic acid administration, for $20 \mathrm{~min}$ the number of writhes was counted $[22,23]$. The extracts and acetylsalicylic acid suspended in tween 80 prior to administration and given orally.

\section{Eddy's hot-plate method:}

The six groups of swiss albino mice were prepared with six animals in each group. First group received normal saline in $3 \%$ tween $80(2 \mathrm{ml} / \mathrm{kg})$ and served as normal control, second group received pentazocine $(5 \mathrm{mg} / \mathrm{kg})$, third and fourth group received 100 and $200 \mathrm{mg} / \mathrm{kg}$ leaves extract, fifth and sixth group received 100 and $200 \mathrm{mg} / \mathrm{kg}$ of bark extract. The individual animal place on the hot plate maintained at temperature of $(55+1)^{0} \mathrm{C}, 15 \mathrm{sec}$ cut-off period considered to avoid the damage to the animal and response recorded for untreated mice such as paw licking or jumping whichever appear first considered at $0 \mathrm{~min}$. $[24,25]$, the response time again observed after treatment at $30,60,120$ and $240 \mathrm{~min}$, and changes in the reaction time were noted.

\section{Statistical analysis}

The one-way analysis of variance (ANOVA) used for the evaluation, and values were exhibits as Mean+SEM, followed by Dunnett's test for multiple comparisons using prism graphpad version 5.0, values of $\mathrm{P}<0.05$ were considered as statistically significant.

\section{Result}

\section{Phytochemical Screening}

The phytochemical analysis of the extract by qualitative study showed the presence triterpenoid and flavonoid and the absence of volatile oils, tannin, alkaloid and saponin.

\section{Acute toxicity studies}

Lantana extract at the dose of $2000 \mathrm{mg} / \mathrm{kg}$ does not exhibited any signs of toxicity up to 14 days and no animals died upon oral administration [26]. Therefore, the biological activity was carried out using $100 \mathrm{mg} / \mathrm{kg}$ and $200 \mathrm{mg} / \mathrm{kg}$ dose levels [27].

\section{Carrageenan induced paw edema}

The bark and leaves extract treated animals showed significant $(P<0.01$ and $P<0.05)$ reduction in paw volume at 100 and $200 \mathrm{mg} / \mathrm{kg}$ dose when compared with standard group from $2 \mathrm{~h}$ onwards (Figure 1 and Table 1 ). Both the extracts showed anti-inflammatory action up to $5 \mathrm{~h}$ of both the doses. The extract treatment reduced inflammation in a dose-dependent manner.

Table 1. MELC effect on carrageenan induced paw edema.

\begin{tabular}{|c|c|c|c|c|c|c|c|}
\hline \multirow[t]{2}{*}{ Treatment } & \multirow[t]{2}{*}{ Dose (mg/kg) } & \multicolumn{6}{|c|}{ Paw edema volume ( $\mathrm{mm}$ ) } \\
\hline & & $0 \mathrm{~h}$ & $1 \mathrm{~h}$ & $2 \mathrm{~h}$ & $3 \mathrm{~h}$ & $4 \mathrm{~h}$ & $5 \mathrm{~h}$ \\
\hline Control & & $1.13+0.12$ & $1.15+0.02$ & $1.35+0.01$ & $1.42+0.02$ & $1.62+0.01$ & $2.16+0.04$ \\
\hline Indomethacin & 10 & $1.15+0.02$ & $1.15+0.22$ & $1.16+0.03^{\star *}$ & $1.22+0.01^{\star *}$ & $1.41+0.01^{\star *}$ & $1.41+0.01^{* *}$ \\
\hline Leaf Extract & 100 & $1.15+0.02$ & $1.16+0.21$ & $1.27+0.00^{* *}$ & $1.32+0.01^{\star *}$ & $1.52+0.02^{\star *}$ & $1.51+0.01^{* *}$ \\
\hline Leaf Extract & 200 & $1.15+0.03$ & $1.18+0.01$ & $1.21+0.01^{\star *}$ & $1.36+0.02^{\star *}$ & $1.47+0.02^{\star *}$ & $1.46+1.23^{* *}$ \\
\hline Bark Extract & 100 & $1.15+0.02$ & $1.18+0.01$ & $1.29+0.02^{*}$ & $1.33+0.01^{\star *}$ & $1.54+0.01^{\star *}$ & $1.52+0.02^{* *}$ \\
\hline Bark Extract & 200 & $1.15+0.03$ & $1.15+0.02$ & $1.20+0.01^{* *}$ & $1.36+0.02^{* *}$ & $1.50+0.02^{\star *}$ & $1.48+0.01^{* *}$ \\
\hline
\end{tabular}

Mean $+\operatorname{SEM}(n=6) .{ }^{*} \mathrm{P}<0.01,{ }^{\star} \mathrm{P}<0.05$ compared with control group. 


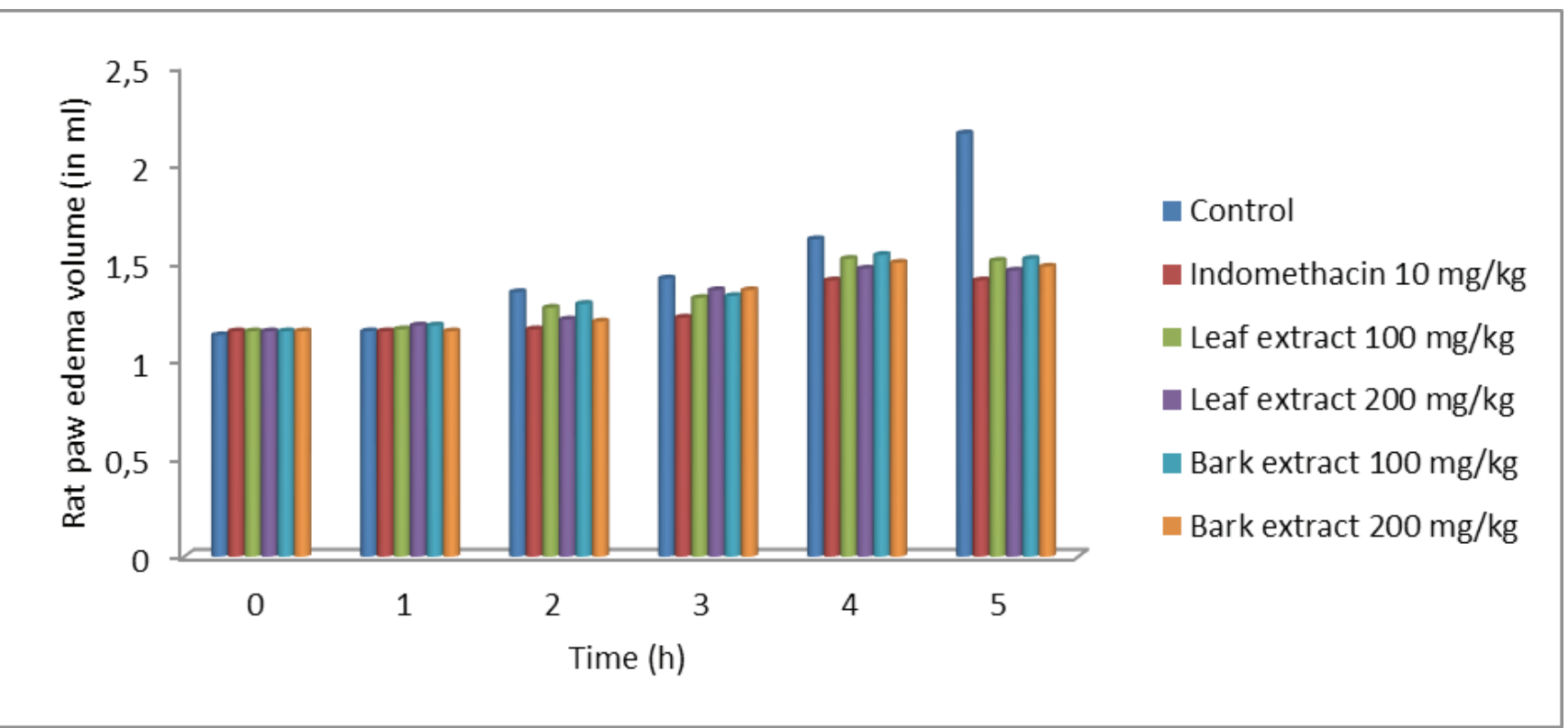

Mean $+\operatorname{SEM}(n=6) .{ }^{*} \mathrm{P}<0.01,{ }^{\star} \mathrm{P}<0.05$ compared with control group.

Figure 1. MELC effect on carrageenan induced paw edema.

\section{Histamine induced edema}

The indomethacin, leaves and bark extract at both the doses showed significant $P<0.01$ and $P<0.05)$ reduction in histamine induced paw edema from $2 \mathrm{~h}$ onwards as compared to the control group ( Figure 2 and Table 2). Both the extract showed anti-inflammatory action up to 5 h of both the doses. The extract shows dose-dependent anti-inflammatory actions.

Table 2. MELC effect on histamine induced paw edema.

\begin{tabular}{|c|c|c|c|c|c|c|c|}
\hline \multirow[t]{2}{*}{ Treatment } & \multirow[t]{2}{*}{ Dose $(\mathrm{mg} / \mathrm{kg})$} & \multicolumn{6}{|c|}{ Paw edema volume ( mm ) } \\
\hline & & $\mathbf{0 h}$ & $1 \mathrm{~h}$ & $2 \mathrm{~h}$ & $3 \mathrm{~h}$ & $4 h$ & $5 \mathrm{~h}$ \\
\hline Control & & $1.08+0.01$ & $1.15+0.02$ & $1.38+0.01$ & $1.42+0.01$ & $1.61+0.01$ & $2.17+0.01$ \\
\hline Indomethacin & 10 & $1.10+0.02$ & $1.15+0.02$ & $1.16+0.03^{\star *}$ & $1.22+0.02^{\star *}$ & $1.40+0.00^{* *}$ & $1.40+0.00^{\star *}$ \\
\hline Leaf Extract & 100 & $1.10+0.03$ & $1.11+0.03$ & $1.28+0.02^{\star *}$ & $1.32+0.01^{\star *}$ & $1.54+0.01^{\star *}$ & $1.52+0.00^{\star *}$ \\
\hline Leaf Extract & 200 & $1.13+0.03$ & $1.19+0.00$ & $1.25+0.01^{\star *}$ & $1.36+0.02^{\star *}$ & $1.50+0.02^{\star *}$ & $1.60+0.01^{\star *}$ \\
\hline Bark Extract & 100 & $1.10+0.01$ & $1.18+0.01$ & $1.29+0.00^{\star \star}$ & $1.34+0.03^{\star *}$ & $1.53+0.00^{\star *}$ & $1.58+0.02^{\star *}$ \\
\hline Bark Extract & 200 & $1.10+0.02$ & $1.18+0.02$ & $1.26+0.01^{\star *}$ & $1.37+0.00^{\star *}$ & $1.55+0.01^{\star}$ & $1.62+0.00^{* *}$ \\
\hline
\end{tabular}

Mean $+\operatorname{SEM}(n=6) .{ }^{* *} \mathrm{P}<0.01,{ }^{\star} \mathrm{P}<0.05$ compared with control group. 


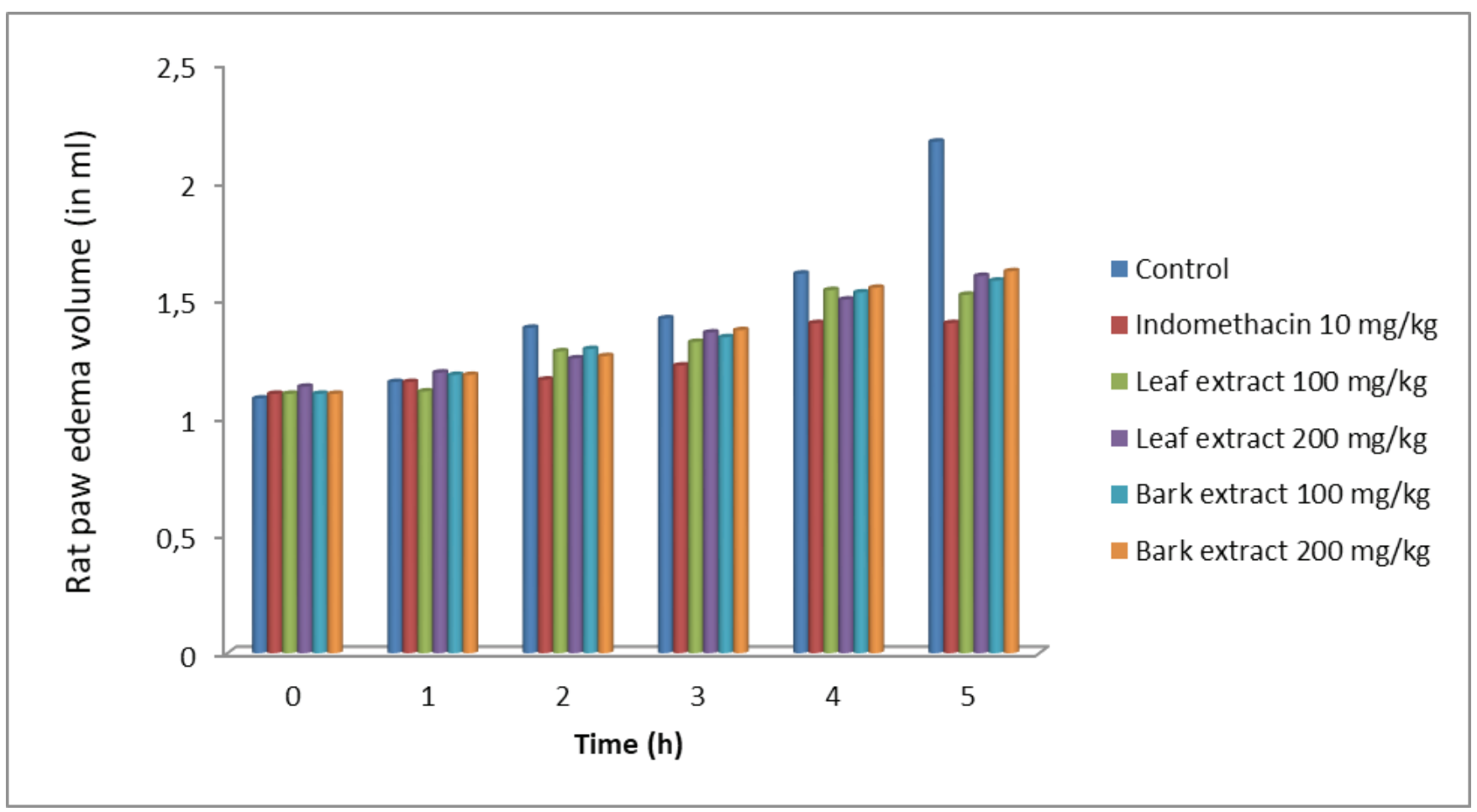

Mean $+\operatorname{SEM}(n=6) .{ }^{*} \mathrm{P}<0.01,{ }^{\star} \mathrm{P}<0.05$ compared with control group.

Figure 2. MELC effect on histamine induced paw edema.

\section{Acetic acid induced writhing}

The acetic acid induced writhing responses in mice. Pretreated MELC and acetylsalicylic acid significantly $(P$
$<0.01)$ inhibited writhing responses as compared to the control group (Figure 3 and Table 3). Also, the $200 \mathrm{mg} / \mathrm{kg}$ leaf and bark extract showed significant $(P<0.01)$ inhibition of writhing responses than $100 \mathrm{mg} / \mathrm{kg}$ dose.

Table 3. Effect of MELC on acetic acid writhing response.

\begin{tabular}{lll}
\hline Treatment & $\begin{array}{l}\text { Dose } \\
(\mathbf{m g} / \mathbf{k g})\end{array}$ & No. of writhing/20 min \\
\hline Control & 100 & $78.5+0.22$ \\
\hline Acetyl salicylic acid & 100 & $29.66+0.42^{* *}$ \\
\hline Leaf Extract & 200 & $46.5+0.42^{\star *}$ \\
\hline Leaf Extract & 100 & $39.5+0.42^{* *}$ \\
\hline Bark Extract & 200 & $48.5+0.22^{* *}$ \\
Bark Extract & $40.16+0.40^{* *}$ \\
\hline
\end{tabular}

Mean $+\operatorname{SEM}(n=6) .{ }^{*} \mathrm{P}<0.01$ MELC leaf and bark extract 100, $200 \mathrm{mg} / \mathrm{kg}$ and acetylsalicylic acid $100 \mathrm{mg} / \mathrm{kg}$ compared with control group. 


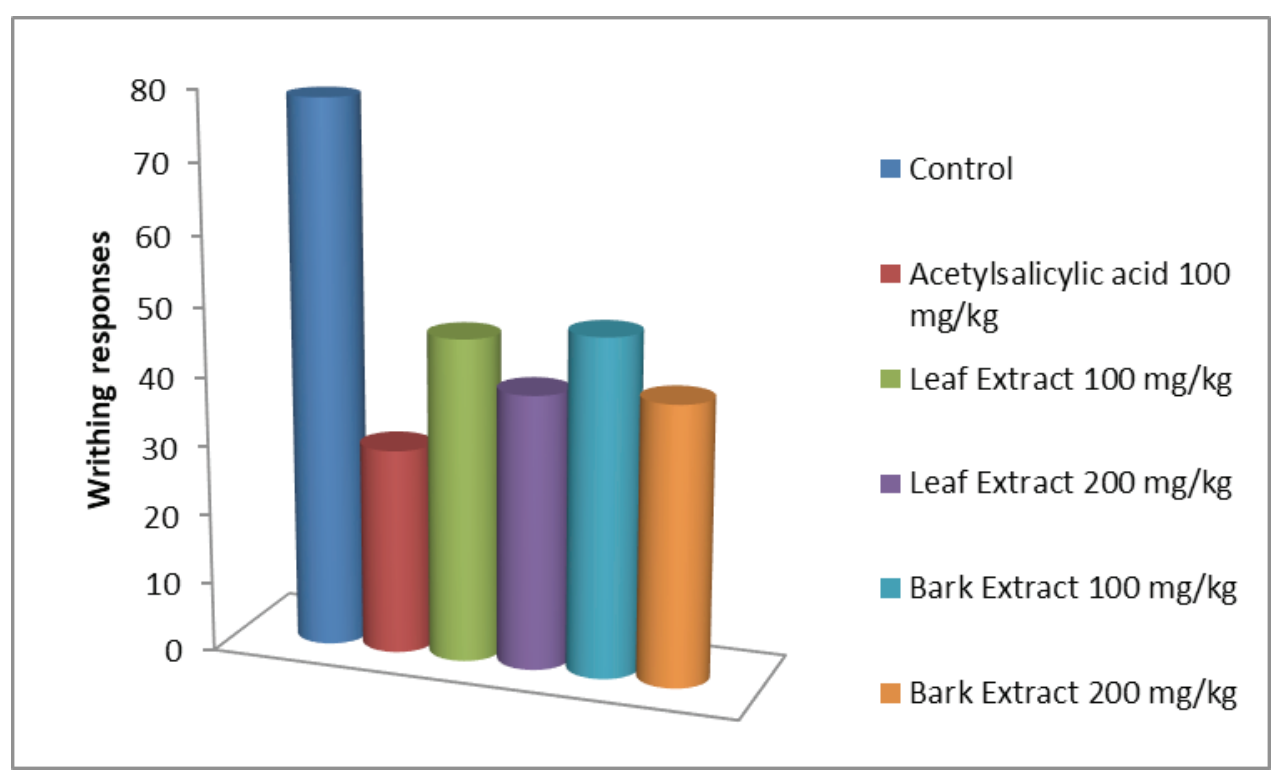

Mean + SEM $(n=6) .{ }^{*} \mathrm{P}<0.01$ MELC leaf and bark extract 100, $200 \mathrm{mg} / \mathrm{kg}$ and acetylsalicylic acid $100 \mathrm{mg} / \mathrm{kg}$ compared with control group.

Figure 3. Effect of MELC on acetic acid writhing response.

\section{Eddy's hot-plate mediated pain reaction}

The pentazocine and MELC (leaf and bark) showed significant $(P<0.05$ and $P<0.01)$ increase in reaction time compared with control group at 100 and $200 \mathrm{mg} / \mathrm{kg}$ dose. (Figure 4 and Table 4.) The MELC $200 \mathrm{mg} / \mathrm{kg}$ produced higher analgesic efficacy $(P<0.01)$ than the MELC $100 \mathrm{mg} /$ $\mathrm{kg}$ dose.

Table 4. Effect of MELC on Eddy's hot-plate induced pain in mice.

\begin{tabular}{|c|c|c|c|c|c|c|}
\hline \multirow[t]{2}{*}{ Treatment } & \multirow[t]{2}{*}{ Dose $(\mathrm{mg} / \mathrm{kg})$} & \multicolumn{5}{|c|}{ Paw Licking response ( Sec) } \\
\hline & & $\mathbf{0 h}$ & $30 \mathrm{~min}$ & $60 \mathrm{~min}$ & $120 \mathrm{~min}$ & $240 \mathrm{~min}$ \\
\hline Control & & $4.93+0.03$ & $4.93+0.03$ & $5.18+0.15$ & $5.1+0.03$ & $5.03+0.05$ \\
\hline Pentazocin & 5 & $4.7+0.13$ & $5.22+0.02$ & $10.02+0.05^{* *}$ & $10.09+0.06^{* *}$ & $12.99+0.05^{\star *}$ \\
\hline Leaf Extract & 100 & $4.49+0.11^{*}$ & $5.3+0.05$ & $6.41+0.08^{\star *}$ & $7.74+0.11^{\star *}$ & $8.48+0.19^{* *}$ \\
\hline Leaf Extract & 200 & $2.71+0.12^{\star *}$ & $11.5+0.13^{\star \star}$ & $15.11+0.04^{* *}$ & $14.91+0.02^{\star *}$ & $14.85+0.03^{\star *}$ \\
\hline Bark Extract & 100 & $4.69+0.10$ & $5.57+0.11^{\star *}$ & $6.56+0.13^{\star \star}$ & $7.65+0.11^{\star \star}$ & $8.67+0.15^{\star \star}$ \\
\hline Bark Extract & 200 & $2.67+0.10^{* *}$ & $11.39+0.18^{\star *}$ & $15.1+0.05^{\star \star}$ & $14.96+0.03^{\star *}$ & $14.94+0.02^{* *}$ \\
\hline
\end{tabular}

Mean $+\operatorname{SEM}(n=6),{ }^{*} P<0.01,{ }^{\star} P<0.05$ MELC (leaf and bark) 100 and $200 \mathrm{mg} / \mathrm{kg}$ and pentazocine $5 \mathrm{mg} / \mathrm{kg}$ compared with control group. 


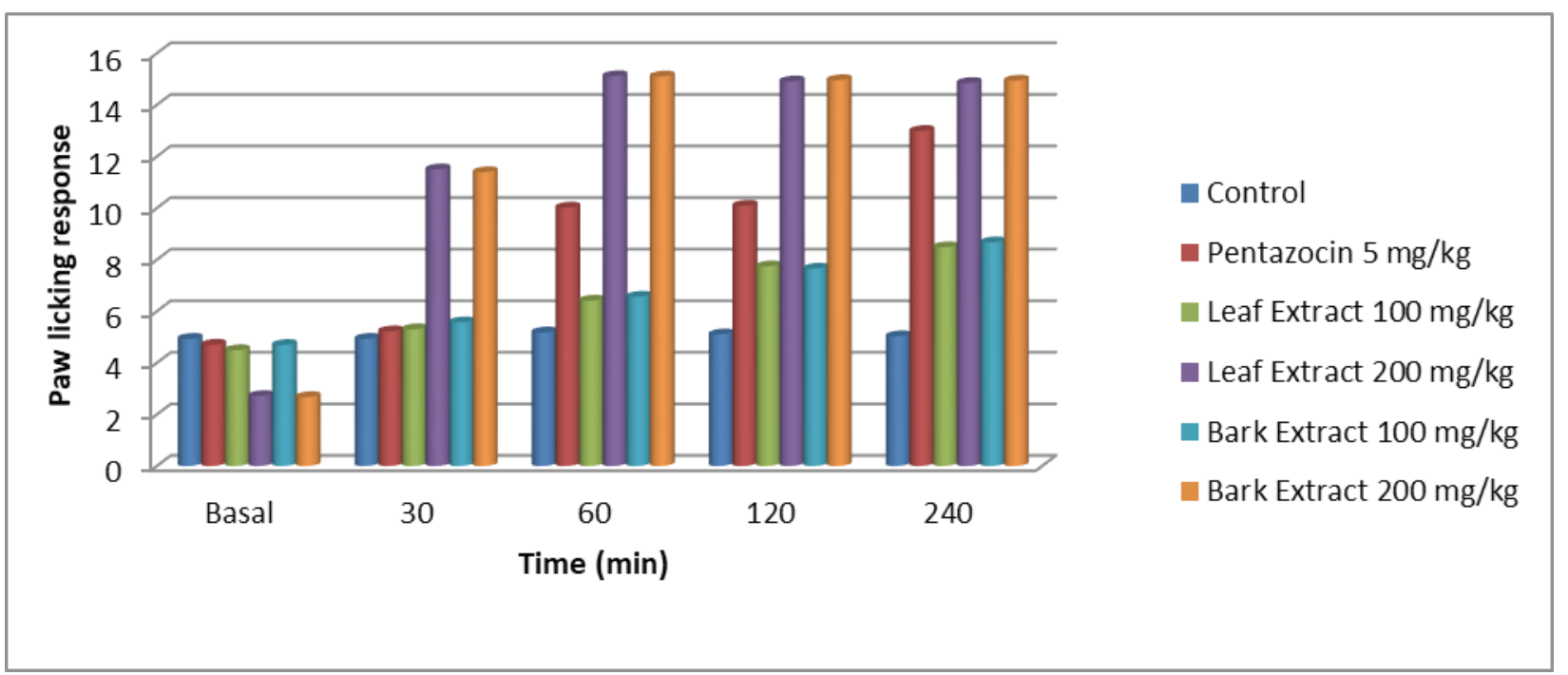

Mean $+\operatorname{SEM}(n=6),{ }^{\star \star} P<0.01,{ }^{\star} P<0.05$ MELC (leaf and bark) 100 and $200 \mathrm{mg} / \mathrm{kg}$ and pentazocine $5 \mathrm{mg} / \mathrm{kg}$ compared with control group.

Figure 4. Effect of MELC on Eddy's hot-plate induced pain in mice.

\section{Discussion}

The various experiments are using carrageenan and histamine induced inflammation model for evaluation of anti-inflammatory activity. Due to the antigenic nature, reproducible and absence of apparent systemic effects carragennan model is commonly used. In the first phase of inflammatory response histamine, kinins and serotonin like inflammatory mediators released. The prostaglandins released in the second phase. Anti-inflammatory actions involved the inhibition of cyclooxygenase, which is responsible for formation of prostanoids, including thromboxane and prostaglandins. Carrageenan and histamine-induced edema are responsible for release of inflammatory mediators. The extract shows inhibition of paw edema induced by histamine and carragennan [28].

At 3, 4 and $5 \mathrm{~h}$ the MELC treated animals showed significant anti-inflammatory activity in carrageenan and histamine induced inflammatory model as compared to control group animals. We have conducted analgesic effects of both the extracts of Lantana camara for evaluation of peripheral and central antiinflammatory action. Acetic acid showed induction of visceral pain, abdominal constrictions in mice due to the production of prostaglandin in the peritoneal fluid [29].

From the above findings, the analgesic action of both the extracts may be due to inhibition of the formation of inflammatory mediators or prevent transmission of inflammatory signals. In hot-plate model the pain perception take place by activation of central nociceptive action mediated at supraspinal level [30].

The opioid receptors mediated actions are responsible for the increase in reaction time after administration of MELC. The central and peripheral analgesic action of both the extract are dose dependant in both the models. The phenolic, flavonoid, and tannin compounds of MELC may responsible for its anti-inflammatory and analgesic action. Although the main chemical constituents of the plant that are the responsible for the analgesic and anti-inflammatory actions still remain speculative.

From above findings the present study represent that extract of L. camara leaf and bark possess anti-inflammatory and analgesic action. These findings support the folkloric use of L. camara.

\section{Conflict of interest statement:}

We declare that we have no conflict of interest.

\section{Acknowledgement:}

The authors are thankful to the Principal, Mula Education Society's College Of Pharmacy, Sonai, Ahmednagar ( $\mathrm{MH}$ ) for providing the necessary facilities in the College. 


\section{References:}

1. Shukla S, Mehta P, Vyas SP, Shukla S, Bajpai VK. Studies on anti-inflammatory, antipyretic and analgesic properties of Caesalpinia bonducella F. seed oil in experimental animal models. Food Chem Toxicol 2010; 48:61-4.

2. Domaj MI, Glassco W, Aceto MD, Martin BR. Antinociceptive and pharmacological effects of metanicotina, a selective nicotine agonist. J Pharmacol Exp Ther 1999; 291: 390-8.

3. Farshchi A, Ghiasi G, Malek Khatabi P, Farzaee H, Niayes A. Antinociceptive effect of promethzine in mice. Iran J Basic Med Sci 2009;12:140-5.

4. Ramchandran S, Rajini Kanth B,Rajsekaran A, Manisenthil Kumar KT. Evaluation of anti- inflammatory and analgesic potential of methanol extract of Tectona grandis flowers. Asian Pac J Trop Biomed 2011; 155-8.

5. Abou-Karam M, Shier WTA. Simplified plaque reduction assay for antiviral agents from plants. Demonstration of frequent occurrence of antiviral activity in higher plants. J Nat Prod 1990; 53: 340-4.

6. Afolayan AJ, Meyer JJM. The antimicrobial activity of 3, 5, 7-trihydroxyflavone isolated from the shoots of Helichrysum aureonitens. J Ethnopharmacol 1997; 57: 177-81.

7. Hernández T, Canales M, Avila JG, Duran A, Caballero J, Romo de Vivar A, Lira R. Ethnobotany and antibacterial activity of some plants used in traditional medicine of Zapotitlán de las Salinas, Puebla (México). J Ethnopharmacol 2003; 88: 181-8.

8. Chellaiah M, Muniappan A, Nagappan R, Savarimuthu I. Medicinal plants used by traditional healers in Kancheepuram District of Tamil Nadu, India. J Ethnobiol Ethnomed 2006; 2: 43.

9. Garg SK, Shah MA, Garg KM. Antilymphocytic and immunosuppressive effects of Lantana camara leaves in rats. Indian J Exp Biol 1997;35: 1315-8.

10. Misra LN, Dixit AK, Sharma RP. High concentration of hepatoprotective oleanolic acid and its derivatives in Lantana camara roots. Planta Medica 1997; 63:582.

11. Noble D, Lane SJ, Sidebottom PJ, Lynn SM. Isolation of translactone-containing triterpenes with thrombin inhibitory activities from the leaves of Lantana camara. J Nat Prod 1998; 61: 1328-31.

12. Raghu C, Ashok G, Suresh B. In vitro cytotoxic activity of Lantana camara Linn. Indian J Pharmacol 2004; 36: 94-5.

13. Adedapo AA, Sofidiya MO, Masika PJ, Afolayan AJ. Antiinflammatory and analgesic activities of the aqueous extract of Acacia karroo stem bark in experimental animals. Basic Clin Pharmacol Toxicol 2008;103:397-400.

14. Trease GE, Evans WC. Text book of Pharmacognosy, 15th edition. Bailliere Tindall, London. 2006, pp. 135-139

15. Bairagi SM, Aher AA, Nema N, Pathan IB. Evaluation of AntiDiarrhoeal activity of the leaves extract of Ficus Microcarpa $L$. (Moracea). Marmara Pharm J 2014;18: 135-8.

16. Pharmacognosy, 1st edition. Editors : Kokate CK, Purohit AP, Gokhle SB. Nirali Prakashan, Pune. 1990, pp 178-181
17. OECD. Guidelines for testing of chemicals, Acute oral toxicity -acute toxic class method. Paris: OECD; 2001. [Online] Available from: http://iccvam.niehs.nih.gov/SuppDocs/ FedDocs/OECD/OECD_GL423.pdf.

18. Valiollah H, Hossein S, Mohsen M, Ahmad M, Ardeshir T. Effect of fluvoxamine on carrageenan-induced paw edema in rats evaluation of action sites. Iran J Pharm Res 2011;10:611-8.

19. Kumar S, Kumar V, Prakash OM. Pharmacognostic study and anti-inflammatory activity of Callistemon lanceolatus leaf. Asian Pacific J Trop Med 2011; 1:177-81.

20. de Alencar NM, Mota MR, Rodrigues NV, Martins JL, do Nascimento KS, Assreuy

21. AM, Cavada BS. Neutrophil-infltrated paw edema induced by mannose-binding Dioclea violacea lectin. Pharmacol Rep 2013; $65: 220-5$.

22. Silva VG, Silva RO, Damasceno SR, Carvalho NS, Prudêncio RS, Aragão KS,Guimarães MA, Campos SA, Véras LM, Godejohann M, Leite JR, Barbosa AL, Medeiros JV.Antiinflammatory and antinociceptive activity of epiisopiloturine, an imidazole alkaloid isolated from Pilocarpus microphyllus. J Nat Prod 2013; 76:1071-7.

23. Pavao Desouza GF, Zarpelon AC, Tedeschi GC, Mizokami SS, Sanson JS, Cunha TM, Ferreira SH, Cunha FQ, Casagrande $\mathrm{R}$, Verri Jr WA.Acetic and phenyl p-benzoquinone induced overt pain like behavior depends on spinal activation of MAP kinases, $\mathrm{PI}_{3} \mathrm{~K}$ and microglia in mice. Pharmacol Biochem Behav 2012;101: 320-8.

24. Nahar L, Zahan R, Tareq M, Haque A, Alam Z, Mosaddik A. Antioxidant, analgesic and CNS depressant activity of Synedrella nodiflora. Pharmacogn J 2012;4:29-36.

25. Wang Y, Chen Y, Xu H, Luo H, Jiang R. Analgesic effect of glycoproteins from Panax ginseng root in mice. J Ethnopharmacol 2013;148: 946-50.

26. Rakh MS, Khedkar AN, Aghav NN, Chaudhari SR. Antiallergic and analgesic activity of Momordica dioica roxb. wild fruit seed. Asian Trop J Biomed 2012; 2: 192-6.

27. Nayak BS, Raju SS, Ramsubhag A. Investigation of wound healing activity of Lantana camara L. in Sprague dawley rats using a burn wound model. Int J Appl Res Nat Prod 2008;1:159.

28. Guideline on acute oral toxicity. Organization for Economic Cooperation and Development (OECD), Paris, France. 2005.

29. Adedapo AA, Sofidiya MO, Masika PJ, Afolayan AJ. Antiinflammatory and analgesic activities of the aqueous extract of Acacia karroo stem bark in experimental animals. Basic Clin Pharmacol Toxicol 2008;103:397-400.

30. Vyas S, Agrawal PR, Solanki P, Trivedi P. Analgesic and antiinflammatory activities of

31. Trigonella foenum-graecum (seed) extract. Acta Pol Pharm 2008; 65: 473-6.

32. Sawadogo WR, Boly R, Lompo M, Some N. Anti-inflammatory, analgesic and antipyretic activities of Dicliptera verticillata. Int J Pharmacol 2006; 2: 435-8. 